\title{
PENGARUH JUMLAH WAJIB PAJAK BADAN, PEMERIKSAAN PAJAK, TINGKAT KEPATUHAN WAJIB PAJAK BADAN TERHADAP PENERIMAAN PAJAK PENGHASILAN DI KPP PRATAMA TAMBORA
}

\author{
MIRANDA TURUSAKA SAU \\ a Sekolah Pascasarjana Fakultas Ekonomi dan Bisnis Universitas Airlangga \\ mirandasau@yandex.com
}

ARTICLE HISTORY

Received:

9 Februari 2019

Revised

5 March 2019

Accepted:

21 March 2019

Online available:

14 Mei 2019

Keywords :

income tax revenue, corporation taxpayer compliance levels,

\begin{abstract}
Directorate General of Taxation difficulties to achieve the target of tax revenue. A number of attempts were made. Through extra efforts, DJP will explore the potential tax revenue. According to Darmin Nasution, to raise the tax rate, the only way is with intensification and extensification. Factors that represent extensification and intensification are the number of taxpayers, number of tax inspection and taxpayer compliance level.

The research aimed to find out whether the revenue of income tax at Tambora Tax Office Service influenced by the number of Corporation Taxpayers, number of tax inspection, and Taxpayer compliance level. The number of Corporation Taxpayers is measured by the number of effective corporation taxpayers. The number of tax inspection is measured by the number of legal products published. The Taxpayer Compliance level is measured from the ratio of the number of Corporation Monthly Tax Return act 25 reported on time with the number of effective corporation taxpayer. The Income Tax revenue is the total revenue of corporation income tax act 25 .

This study used multiple linier regression with quantitative data that obtained from Tambora Tax Service Office for the period of Januari 2010 untill Juni 2013. This research states that the number of Corporation Taxpayers, Taxpayer compliance level has an influence on the income tax revenue at Tambora Tax Office Service. While the number of tax inspection does not have an influence on the income tax revenue at Tambora Tax Office Service.
\end{abstract}




\section{LATAR BELAKANG}

Seperti yang diketahui oleh masyarakat luas di Indonesia bahwa pajak adalah hal yang sangat penting dalam menunjang pembangunan di negara ini. Namun apabila melihat fenomena yang terjadi maka penerimaan akan pajak di negara ini bisa terhambat. Hal itu berarti keberlangsungan kepentingan untuk masyarakat secara luas juga ikut terhambat. Oleh karena itu sangat penting bagi pemerintah khususnya Direktorat Jendral Pajak (Ditjen Pajak) untuk mencari cara agar penerimaan pajak tetap bisa sesuai dengan target.

Menurut Darmin Nasution (Media Indonesia, 2007) menyatakan bahwa untuk menaikkan rasio perpajakan, satu-satunya cara adalah dengan intensifikasi dan ekstensifikasi. Intensifikasi yakni dengan membenahi pembayaran pajak dari sektor ke sektor. Di lain pihak, ekstensifikasi dilakukan untuk membidik wajib pajak baru karena potensi calon wajib pajak sangat besar. Sehingga merupakan hal yang penting untuk melakukan penelitian dengan mengkombinasikan kedua aspek pendekatan tersebut yaitu kombinasi dari ekstensifikasi dan intensifikasi di dalam perpajakan.

Faktor yang sangat dominan mewakili ekstensifikasi dan intensifikasi pajak dalam hal akan diuji pengaruhnya terhadap penerimaan pajak yaitu faktor jumlah wajib pajak, tingkat kepatuhan wajib pajak serta pemeriksaan pajak. Hal ini pun dijelaskan pada aturan pelaksanaan ekstensifikasi dan intensifikasi pajak dalam Surat Edaran Direktorat Jenderal Pajak No. SE-06/PJ.09/2001, di mana pengertian "ektensifikasi adalah kegiatan yang berkaitan dengan penambahan jumlah wajib pajak yang terdaftar." Kemudian pengertian "intensifikasi adalah kegiatan optimalisasi penggalian penerimaan pajak seperti melakukan kegiatan pemeriksaan guna menguji kepatuhan wajib pajak."

Berkaitan dengan penerimaan pajak di Indonesia, pemerintah khususnya Direktorat Jendral Pajak memberikan target penerimaan yang harus dicapai oleh masingmasing Kantor Pelayanan Pajak (KPP) tiap tahunnya. Target penerimaan pajak didasarkan atas besaran potensi dari masing-masing daerah lingkupnya. Salah satu KPP yang berpotensi cukup besar dalam hal pencapaian realisasi penerimaan pajak yaitu KPP Pratama Jakarta Tambora. pada tahun 2010 sampai dengan tahun 2011 persentase realisasi penerimaan melebihi target. Tahun 2010 sebesar 103,2\% dan tahun 2011 sebesar 126,12\%. Hal ini menunjukkan bahwa KPP mampu mencapai target yang diberikan oleh DJP. Namun kinerja KPP mengalami penurunan pada tahun 2012 dan tahun 201. Pada tahun 2012 hanya sebesar 96,50\% dan tahun 2013 sebesar 81,45\%. Oleh karena itu, faktor mengenai penerimaan pajak pada KPP Pratama Jakarta Tambora perlu untuk diteliti.

Berdasarkan data dari KPP setempat, kontribusi terhadap penerimaan pajak sektor perdagangan besar dan eceran menempati peringkat pertama yaitu sebesar 
48,03\%. Dan apabila dilihat dari jenis wajib pajak, wajib pajak badan mendominasi kontribusi terhadap penerimaan pajak yaitu sebesar $58,64 \%$. Oleh karena itu pemilihan populasi dengan menggunakan wajib pajak badan pada KPP Tambora merupakan hal yang tepat dalam hal dilakukan penelitian.

\section{TINJAUAN PUSTAKA}

Wajib Pajak

Dalam pasal 2 ayat 1 pada Undang-Undang Nomor 6 Tahun 1983 sebagaimana telah diubah terakhir dengan UU No 16 Tahun 2009 tentang Ketentuan Umum dan Tata Cara Perpajakan (UU KUP) (Fitriandi, $d k k ., 2010)$ dijelaskan bahwa:

setiap wajib pajak yang telah memenuhi persyaratan subjektif dan objektif sesuai dengan ketentuan peraturan perundang-undangan perpajakan wajib mendaftarkan diri pada kantor Direktorat Jenderal Pajak yang wilayah kerjanya meliputi tempat tinggal atau tempat kedudukan Wajib Pajak dan kepadanya diberikan NPWP.

Adapun kewajiban Wajib Pajak setelah memiliki NPWP yang tertera pada UndangUndang Nomor 6 Tahun 1983 sebagaimana telah diubah terakhir dengan UU No 16 Tahun 2009 tentang Ketentuan Umum dan Tata Cara Perpajakan (Fitriandi, dkk., 2010) adalah sebagai berikut:

1. Dalam pasal 4 dijelaskan bahwa wajib pajak wajib mengisi dan menyampaikan Surat Pemberitahuan dengan benar, lengkap, jelas dan menandatanganinya. Dalam hal wajib pajak adalah badan maka Surat Pemberitahuan harus ditandatangani oleh pengurus atau direksi. Surat Pemberitahuan Tahunan Pajak Penghasilan bagi Wajib Pajak yang wajib menyelenggarakan pembukuan harus dilampiri dengan laporan keuangan berupa neraca dan laporan laba rugi serta keterangan lain yang diperlukan untuk menghitung besarnya Penghasilan Kena Pajak.

2. Dalam pasal 10 dijelaskan bahwa Wajib Pajak wajib membayar atau menyetor pajak yang terutang dengan menggunakan Surat Setoran Pajak ke kas negara melalui tempat pembayaran yang diatur dengan atau berdasarkan Peraturan Menteri Keuangan.

Dengan demikian apabila terdapat penambahan terhadap jumlah wajib pajak (syarat subjektif dan objektif terpenuhi) maka terdapat pula penambahan penerimaan pajak dikarenakan wajib pajak tersebut memiliki kewajiban untuk menghitung, memperhitungkan, menyetor dan melaporkan perpajakannya.

\section{Pemeriksaan Pajak}

Pada pasal 2 dalam Peraturan Menteri Keuangan Republik Indonesia Nomor: 17/PMK.03/2013 tentang Tata Cara Pemeriksaan (Menteri Keuangan, 2013) menyatakan 
bahwa "Direktur Jenderal Pajak berwenang melakukan Pemeriksaan dengan tujuan untuk menguji kepatuhan pemenuhan kewajiban perpajakan dan/atau untuk tujuan lain dalam rangka melaksanakan ketentuan peraturan perundang-undangan perpajakan." Di mana pemeriksaan pajak berkaitan erat dengan laporan pemeriksaan pajak. Laporan pemeriksaan pajak merupakan laporan tentang hasil pemeriksaan yang disusun oleh pemeriksa pajak secara ringkas dan jelas serta sesuai dengan ruang lingkup dan tujuan pemeriksaan. Laporan pemeriksaan pajak inilah yang digunakan sebagai dasar penerbitan produk hukum seperti berbagai Surat Ketetapan Pajak dan Surat Tagihan Pajak.

Produk-produk hukum hasil pemeriksaan adalah sebagai berikut:

1. Surat Ketetapan Pajak Kurang Bayar (SKPKB).

Pada pasal 1 ayat 16 UU KUP berbunyi: "Surat Ketetapan Pajak Kurang Bayar adalah surat ketetapan pajak yang menentukan besarnya jumlah pokok pajak, jumlah kredit pajak, jumlah kekurangan pembayaran pokok pajak, besarnya sanksi administrasi, dan jumlah pajak yang masih harus dibayar."

2. Surat Ketetapan Pajak Kurang Bayar Tambahan (SKPKBT).

Pada pasal 1 ayat 17 UU KUP berbunyi: "Surat Ketetapan Pajak Kurang Bayar Tambahan adalah surat ketetapan pajak yang menentukan tambahan atas jumlah pajak yang telah ditetapkan."

3. Surat Ketetapan Pajak Lebih Bayar (SKPLB).

Pada pasal 1 ayat 19 UU KUP berbunyi: "Surat Ketetapan Pajak Lebih Bayar adalah surat ketetapan pajak yang menentukan jumlah kelebihan pembayaran pajak karena jumlah kredit pajak lebih besar daripada pajak yang terutang atau seharusnya tidak terutang."

4. Surat Ketetapan Pajak Nihil (SKPN).

Pada pasal 1 ayat 18 UU KUP berbunyi: "Surat Ketetapan Pajak Nihil adalah surat ketetapan pajak yang menentukan jumlah pokok pajak sama besarnya dengan jumlah kredit pajak atau pajak tidak terutang dan tidak ada kredit pajak."

5. Surat Tagihan Pajak (STP).

Pada pasal 1 ayat 20 UU KUP berbunyi: "Surat Tagihan Pajak adalah surat untuk melakukan tagihan pajak dan/atau sanksi administrasi berupa bunga dan/atau denda."

Dengan demikian untuk mengimbangi pelaksanaan sistem self-assesment maka ditetapkanlah suatu mekanisme pemeriksaan pajak. Dalam hal ini fiskus berperan aktif dalam pelaksanaannya serta wajib memberikan hasil pemeriksaan berupa produkproduk hukum. Produk-produk hukum ini berpotensi untuk meningkatkan penerimaan pajak. 


\section{Kepatuhan Wajib Pajak}

Definisi kepatuhan perpajakan menurut Nurmantu (2005) adalah "suatu keadaan di mana wajib pajak memenuhi semua kewajiban perpajakan dan melaksanakan hak perpajakannya." Umumnya kepatuhan wajib pajak diukur dari ketaatannya dalam membayar dan melaporkan pajaknya, apakah telah dilakukan dengan benar sesuai dengan peraturan yang berlaku. Kepatuhan dalam perpajakan terdiri dari dua jenis yaitu kepatuhan formal dan kepatuhan material. Kepatuhan formal adalah suatu keadaan di mana wajib pajak memenuhi kewajiban perpajakan secara formal sesuai dengan ketentuan dalam Undang-Undang Perpajakan. Misalnya ketentuan tentang batas waktu penyampaian SPT Masa maupun Tahunan. Sedangkan kepatuhan material adalah suatu keadaan di mana wajib pajak secara substantif/ hakekat memenuhi semua ketentuan material perpajakan. Kepatuhan material dapat meliputi kepatuhan formal. Wajib pajak yang memenuhi kepatuhan material dalam mengisi SPT adalah wajib pajak yang mengisi SPT dengan jujur, baik dan benar sesuai dengan ketetuan dalam Undang-Undang Perpajakan dan menyampaikan ke Kantor Pelayanan Pajak tepat waktu.

\section{Penerimaan Pajak Penghasilan}

Pajak penghasilan adalah pajak yang dikenakan terhadap wajib pajak berkenaan dengan penghasilan diterima atau diperolehnya dalam tahun pajak. Di mana PPh Pasal 25 menurut Undang-Undang Nomor 7 tahun 1983 sebagaimana telah diubah terakhir dengan Undang-Undang Nomor 36 Tahun 2008 tentang Pajak Penghasilan(Fitriandi, $d k k ., 2010)$ adalah besarnya angsuran pajak penghasilan yang harus dibayar sendiri oleh wajib pajak untuk setiap bulan sekali dalam tahun pajak berjalan.

Dalam Peraturan Dirjen Pajak Nomor PER-22/PJ/2008 tentang Tata Cara Pembayaran dan Pelaporan Pajak Penghasilan Pasal 25 (Direktur Jenderal Pajak, 2008) dalam pasal 3 dan 4 dijelaskan bahwa:

1. Pembayaran pajak harus harus dibayar/disetor selambat-lambatnya tanggal lima belas bulan takwim berikutnya dan dilakukan dengan menggunakan Surat Setoran Pajak (SSP) atau sarana administrasi lain yang disamakan dengan Surat Setoran Pajak

2. Dalam hal pelaporan:

a. Wajib Pajak yang melakukan pembayaran PPh Pasal 25 pada tempat pembayaran dan SSP nya telah mendapat validasi dengan NTPN, maka Surat Pemberitahuan Masa PPh Pasal 25 dianggap telah disampaikan ke Kantor Pelayanan Pajak sesuai dengan tanggal validasi yang tercantum pada SSP. 
Wajib Pajak dengan jumlah angsuran PPh Pasal 25 Nihil atau angsuran PPh Pasal 25 dalam bentuk satuan mata uang selain rupiah atau yang melakukan pembayaran tidak secara on-line dan tidak mendapat validasi dengan NTPN, tetap harus menyampaikan Surat Pemberitahuan Masa PPh Pasal 25 sesuai dengan ketentuan yang berlaku.

\section{METODE PENELITIAN}

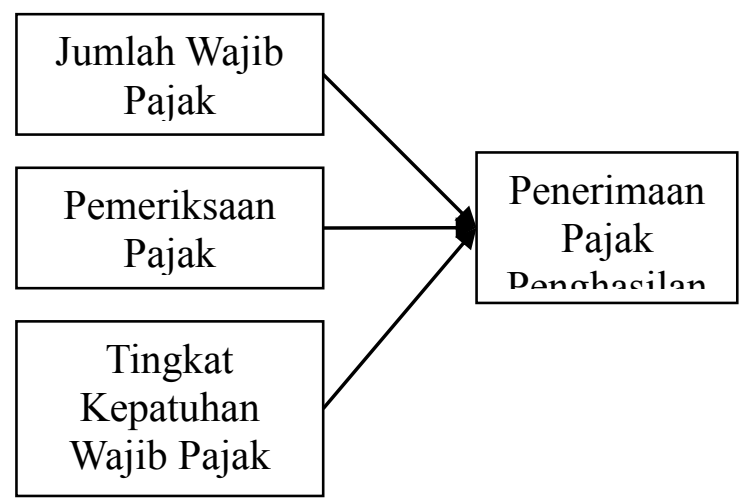

Gambar 1. Skema Rerangka Konseptual Penelitian

\section{$\underline{\text { Hipotesis }}$}

Setiap wajib pajak yang terdaftar akan diberikan NPWP sebagai sarana administrasi perpajakannya. Di mana kewajiban wajib pajak setelah memiliki NPWP adalah wajib mengisi SPT dengan benar serta menyetorkan pajak atas penghasilan dengan menggunakan SSP dan melaporkan perhitungan atas pajak tersebut. Sehingga semakin banyak jumlah wajib pajak maka semakin besar penerimaan pajak yang diterima oleh KPP. Hal tersebut didukung oleh penelitian yang diteliti oleh Tresno, dkk., (2011) serta Fitriani W \& Saputra (2009) yang menyatakan bahwa jumlah wajib pajak terdaftar berpengaruh terhadap penerimaan pajak. Maka hipotesis pertama yang diajukan adalah: $\mathrm{H}_{1}$ : Jumlah wajib pajak badan berpengaruh terhadap penerimaan Pajak Penghasilan di KPP Pratama Jakarta Tambora.

Untuk mengimbangi pelaksanaan sistem self-assesment maka ditetapkanlah suatu mekanisme pemeriksaan pajak. Berdasarkan UU KUP Pasal 29 menyatakan bahwa DJP berwenang melakukan pemeriksaan guna menguji kepatuhan dan tujuan lain dalam perpajakan. Dalam hal ini fiskus berperan aktif dalam pelaksanakannya serta wajib memberikan hasil pemeriksaan berupa produk-produk hukum. Produk-produk hukum ini berpotensi untuk meningkatkan penerimaan pajak. Hal tersebut didukung oleh penelitian yang dilakukan oleh Herryanto \& Toly (2013) yang menyatakan bahwa 
pemeriksaan pajak berpengaruh terhadap penerimaan pajak. Maka hipotesis kedua yang diajukan adalah:

$\mathrm{H}_{2}$ : Pemeriksaan pajak berpengaruh terhadap penerimaan Pajak Penghasilan di KPP Pratama Jakarta Tambora.

Tingkat kepatuhan wajib pajak mencerminkan ketaatan wajib pajak akan undangundang perpajakan yang berlaku. Apabila tingkat kepatuhan wajib pajak semakin tinggi maka semakin banyak wajib pajak yang melaporkan pajak atas penghasilannya secara benar. Dengan demikian maka penerimaan pajak pun akan meningkat. Hal tersebut didukung oleh penelitian yang dilakukan oleh Hernadi (2012), Suhendra (2010), Fitriani W \& Saputra (2009), Suryadi (2006) yang menyatakan bahwa tingkat kepatuhan wajib pajak berpengaruh terhadap penerimaan pajak Maka hipotesis ketiga yang diajukan adalah:

$\mathrm{H}_{3}$ : Tingkat Kepatuhan wajib pajak badan berpengaruh terhadap penerimaan Pajak Penghasilan di KPP Pratama Jakarta Tambora.

Jenis penelitian yang digunakan yaitu penelitian kuantitatif. Penelitian kuantitatif mempunyai tujuan untuk menguji teori, meletakkan teori menjadi landasan dalam penemuan dan pemecahan penelitian (Sugiyono, 2003). Dengan populasi yang digunakan adalah wajib pajak badan yang terdaftar di KPP Pratama Jakarta Tambora per bulan dari tahun 2010-2013. Dalam penelitian ini menggunakan sensus di mana sampel adalah keseluruhan dari populasi yang berjumlah 5.639 wajib pajak.

Variabel dalam penelitian ini terdiri dari empat variabel yaitu tiga variabel independen/bebas dan satu variabel dependen/terikat. Variabel independen (X) yang terdiri dari:

1. Jumlah Wajib Pajak Badan $\left(X_{1}\right)$

Variabel ini diukur dari jumlah wajib pajak badan yang efektif di KPP Pratama Jakarta Tambora per bulan dari bulan Januari 2010 sampai dengan bulan Juni 2013. Data ini menggunakan skala pengukuran rasio.

\section{Pemeriksaan Pajak $\left(\mathrm{X}_{2}\right)$}

Variabel ini diukur dari banyaknya pemeriksaan pajak atas wajib pajak badan yang tercermin dari jumlah produk hukum pemeriksaan (SKPKB, SKPKBT, SKPN, SKPLB, STP) yang diterbitkan oleh KPP Pratama Jakarta Tambora mulai dari bulan Desember 2009 sampai dengan bulan Juni 2013, di mana jumlah pemeriksaan yang tercantum dalam bulan tersebut merupakan produk hukum yang terbit pada bulan sebelumnya. Data ini menggunakan skala pengukuran rasio.

\section{Tingkat Kepatuhan Wajib Pajak Badan $\left(\mathbf{X}_{3}\right)$}


Variabel ini diukur dari jumlah SPT Masa PPh 25 yang dilaporkan oleh WP badan dengan tepat waktu setiap bulannya dari bulan Januari 2010 sampai dengan bulan Juni 2013. Jumlah SPT Masa PPh pasal 25 dihitung dengan cara jumlah SPT Masa yang masuk tepat waktu dibagi keseluruhan SPT Masa yang seharusnya disetor/dilaporkan dikali 100\%. Penyampaian SPT Masa PPh 25 dianggap tepat waktu apabila disampaikan paling lambat 20 hari setelah Masa Pajak berakhir. Data ini menggunakan skala pengukuran rasio.

\section{Penerimaan Pajak Penghasilan (Y)}

Variabel ini diukur dari jumlah penerimaan pajak penghasilan pasal 25 wajib pajak badan yang diterima KPP Pratama Jakarta Tambora per bulan dari bulan Januari 2010 sampai dengan bulan Juni 2013 (berdasarkan masa pajak). Data ini menggunakan skala pengukuran rasio.

\section{Teknik Analisis Data}

Pengujian hipotesis dilakukan dengan dengan menggunakan Analisis Regresi Linear Berganda di mana untuk melihat pengaruh secara linier antara dua atau lebih variabel independen dengan variabel dependen.

\section{HASIL PENELITIAN DAN ANALISA}

Table 1

Output Uji Regresi
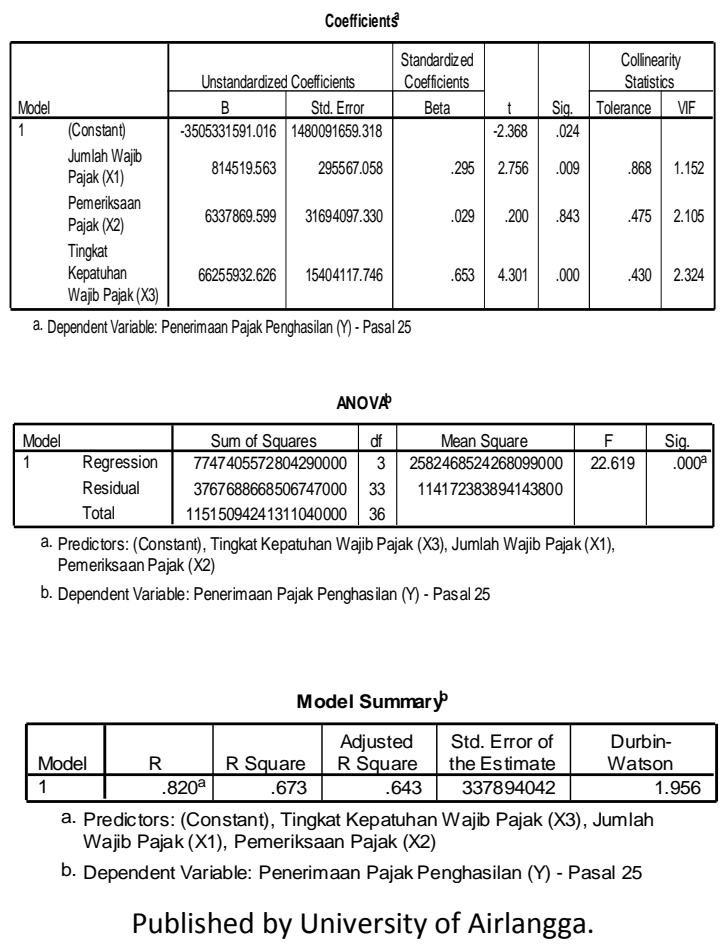

This is an open access article under the CC BY license (https://creativecommons.org/licenses/by-sa/4.0/) 
Model persamaan regresi yang dihasilkan adalah:

$Y=-3.505 .331 .591,016+814.519,563 X_{1}+6.337 .869,599 X_{2}+66.255 .932,626 X_{3}$

Koefisien Determinasi $\left(R^{2}\right)$ sebesar 0,673 , memiliki arti bahwa variabel Jumlah wajib pajak badan $\left(X_{1}\right)$, jumlah pemeriksaan pajak $\left(X_{2}\right)$, tingkat kepatuhan wajib pajak badan $\left(X_{3}\right)$, dapat mempengaruhi sebesar 67,3\% penerimaan PPh Pasal 25 Badan di KPP Pratama Jakarta Tambora, sedangkan sisanya yaitu sebesar 32,7,7\% dipengaruhi oleh variabel lainnya yang tidak diteliti.

\section{Pembahasan}

Hasil pertama penelitian ini, variabel jumlah wajib pajak badan $\left(X_{1}\right)$ berpengaruh signifikan terhadap penerimaan PPh 25 dengan p value 0,009 (lebih kecil dari 0,05). Hasil penelitian ini mendukung hasil penelitian Tresno, dkk., (2011), dan Fitriani W \& Saputra (2009) yang menemukan bahwa jumlah wajib pajak berpengaruh terhadap penerimaan pajak. Tresno, dkk., (2011) mengungkapkan bahwa "logikanya setiap terjadi penambahan jumlah wajib pajak maka akan diiringi dengan meningkatnya jumlah penerimaan pajak penghasilan yang signifikan. Penambahan jumlah wajib pajak yang seperti inilah yang diharapkan dapat meningkatkan penerimaan pajak penghasilan pada masa-masa berikutnya."

Hasil kedua penelitian ini, variabel pemeriksaan pajak $\left(X_{2}\right)$ tidak berpengaruh signifikan terhadap penerimaan PPh 25 dengan $p$ value 0,843 (lebih besar dari 0,05) dan bertanda positif. Hasil penelitian ini menunjukkan hasil yang sama dengan penelitian Kosasih (2008) dan Suhendra (2010) yang menemukan bahwa pemeriksaan pajak tidak berpengaruh terhadap penerimaan pajak namun hasil ini juga tidak signifikan. Hasil penelitian menunjukkan bahwa pemeriksaan pajak tidak berpengaruh terhadap penerimaan pajak. Hal ini dikarenakan kurang optimalnya aparat pajak pada KPP setempat dalam melaksanakan pemeriksaan (berdasarkan data penelitian yang diperoleh). Seharusnya pemeriksaan pajak merupakan hal yang penting mengingat sistem perpajakan di Indonesia adalah self-assesment. Jumlah pemeriksaan pajak mempunyai peran dalam peningkatan penerimaan pajak apabila dilaksanakan secara optimal.

Hasil ketiga penelitian ini, variabel tingkat kepatuhan wajib pajak badan $\left(X_{3}\right)$ berpengaruh signifikan terhadap penerimaan PPh 25 dengan $p$ value 0,000 (baca: mendekati nol) dan bertanda positif. Hasil penelitian ini mendukung hasil penelitian Hernadi (2012), Suhendra (2010), Fitriani W \& Saputra (2009), serta Suryadi (2006) yang menemukan bahwa tingkat kepatuhan wajib pajak berpengaruh terhadap penerimaan 
pajak. Tingkat kepatuhan yang tinggi sangat diperlukan dalam sistem perpajakan di Indonesia yang menuntut keikutsertaan aktif wajib pajak dalam kewajiban perpajakannya. Kemudian pelayanan yang baik akan mendorong kepatuhan wajib pajak untuk melaksanakan kewajiban perpajakannya. Pelayanan harus terus ditingkatkan dan database management harus dikembangkan secara akurat, terintegrasi dan terjamin kerahasiaannya sehingga dapat digunakan untuk mendukung kegiatan pelayanan perpajakan (Darussalam,2010).

\section{KESIMPULAN}

Berdasarkan hasil pengujian hipotesis yang dilakukan pada bab sebelumnya dengan menggunakan analisis regresi berganda, maka disimpulkan bahwa:

1. Jumlah wajib pajak badan berpengaruh positif terhadap penerimaan pajak penghasilan di KPP Pratama Jakarta Tambora. Hasil penelitian ini mendukung hasil penelitian Tresno, dkk., (2011), dan Fitriani W \& Saputra (2009) karena logikanya setiap terjadi penambahan jumlah wajib pajak maka akan diiringi dengan meningkatnya jumlah penerimaan pajak penghasilan. Akan tetapi dalam prakteknya, KPP kurang bekerja sama dalam pencarian data dengan kantor pusat serta kadang kala perubahan profil-profil wajib pajak yang ada pada seksi pengawasan dan konsultasi belum terupdate pada Master File Local (MFL) milik seksi pengolahan data dan informasi.

2. Pemeriksaan pajak tidak berpengaruh terhadap penerimaan pajak penghasilan di KPP Pratama Jakarta Tambora. Hasil penelitian ini mendukung hasil penilitian Kosasih (2008) dan Suhendra (2010) karena pemeriksaan pajak yang dilakukan kurang optimal (berdasarkan data yang diperoleh) sehingga menyebabkan tidak adanya pengaruh terhadap penerimaan pajak.

Tingkat kepatuhan wajib pajak badan berpengaruh positif terhadap penerimaan pajak penghasilan di KPP Pratama Jakarta Tambora. Hasil penelitian ini mendukung hasil penelitian Hernadi (2012), Suhendra (2010), Fitriani W \& Saputra (2009), serta Suryadi (2006) karena dengan adanya kesadaran dari wajib pajak akan hak dan kewajibannya dalam perpajakan maka dapat berakibat pada tingginya kepatuhan wajib pajak yang berpengaruh terhadap penerimaan pajak. 


\section{DAFTAR REFERENSI}

Darussalam, Danny. 2010. Peningkatan Kepatuhan Wajib Pajak Melalui Komite Pengawas Perpajakan, diakses melalui http://www.ortax.org/ortax/?mod=issue\&page=show\&id=43\&q=\&hlm=2 pada tanggal 11 September 2014.

Direktur Jenderal Pajak. 2001. SE-06/PJ.9/2001 tentang Pelaksanaan Ekstensifikasi dan Intensifikasi Pajak, diakses melalui http://www.ortax.org/ortax/?mod=aturan\&id topik=\&id jenis=7100\&p tgl=tahu n\&tahun $=2001 \&$ nomor $=6 \& q=\& q d o=$ macth \&cols $=i s i \& x=55 \& y=23 \& h / m=1 \&$ page $=s$ how\&id=1867\#aturanright pada tanggal 11 Maret 2014.

Direktur Jenderal Pajak. 2008. PER-22/PJ/2008 tentang Tata Cara Pembayaran dan Pelaporan Pajak Penghasilan Pasal 25, diakses melalui http://www.ortax.org/ortax/?mod=aturan\&id topik=\&id jenis=\&p tgl=tahun\&ta hun=2008\&nomor $=22 \& q=\& q$ do=macth \&cols=isi \&x=63\&y=18\&hlm=1\&page=sh ow\&id=13249\#aturanright pada tanggal 11 Maret 2014.

Fitriandi, P., Y. Aryanto., \& A.P. Priyono. 2010. Undang-Undang Nomor 6 Tahun 1983 sebagaimana telah diubah terakhir dengan Undang-Undang Nomor 16 Tahun 2009 tentang Ketentuan Umum dan Tata Cara Perpajakan. Dalam: Kompilasi Undang-Undang Perpajakan. Jakarta: Salemba Empat, hal. 4-94.

Fitriandi, P., Y. Aryanto., \& A.P. Priyono. 2010. Undang-Undang Nomor 7 Tahun 1983 sebagaimana telah diubah terakhir dengan Undang-Undang Nomor 36 Tahun 2008 Tentang Undang-Undang Pajak Penghasilan. Dalam: Kompilasi UndangUndang Perpajakan. Jakarta: Salemba Empat, hal. 95-190.

Fitriani W, Dina. \& P.M.A. Saputra. 2009. Analisa Faktor-Faktor yang Mempengaruhi Jumlah Penerimaan Pajak Penghasilan Orang Pribadi. Journal of Indonesian Applied of Economics. (Vol.3): 135-149.

Harian Kontan. 2013. Kejar Target Penerimaan, Ditjen Pajak Gali Potensi Penerimaan, diakses melalui http://www.ortax.org/ortax/?mod=berita\&page=show\&id=12945\&q=\&hlm=10\# pada tanggal 25 Februari 2014.

Harian Kontan, 2014. Kantor Pajak Berpotensi Gagal Mencapai Target Lagi Tahun Ini, diakses melalui http://www.ortax.org/ortax/?mod=berita\&page=show\&id $=13309 \& \mathrm{q}=\& \mathrm{~h} / \mathrm{m}=6$ pada tanggal 25 Februari 2014. 
Hernadi, I. 2012. Pengaruh Penagihan Pajak dan Kepatuhan Wajib Pajak terhadap Penerimaan Pajak. Jurnal Universitas Komputer Indonesia.

Herryanto, M. \& A.A. Toly. 2013. Pengaruh Kesadaran Wajib Pajak, Kegiatan Sosialisasi Perpajakan, dan Pemeriksaan Pajak terhadap Penerimaan Pajak Penghasilan di KPP Pratama Surabaya Sawahan. Tax \& Accounting Review. (Vol.1): 124-135.

Kosasih. 2008. Analisa Jumlah Wajib Pajak dan Pemeriksaan Pajak terhadap Realisasi Penerimaan Pajak pada Kantor Pajak XXX. Jurnal Manajemen. (Vol. 6): 271-286.

Media Indonesia. 2007. Tax Ratio Indonesia Masih Rendah, diakses melalui http://www.ortax.org/ortax/?mod=berita \&page=show\&id=679\&q=\&h/m=893 pada tanggal 23 Februari 2014.

Menteri Keuangan. 2013. PMK No.17/PMK.03/2013 tentang Tata Cara Pemeriksaan, diakses

melaluihttp://www.ortax.org/ortax/?mod=aturan\&id topik=\&id jenis=\&p tgl=ta hun \&tahun=2013\&nomor $=17 \& q=\& q$ do=macth \&cols=isi $\& x=76 \& y=12 \& \mathrm{hlm}=1 \& p$ age=show\&id=15207 pada tanggal 11 Maret 2014.

Nurmantu, S. 2005. Pengantar Perpajakan Edisi Ketiga. Jakarta: Granit.

Pajak.go.id.2012.Strategi Meningkatkan Kepatuhan Wajib Pajak, diakses melalui http://www.pajak.go.id/content/strategi-meningkatkan-kepatuhan-wajib-pajak pada tanggal 11 September 2014

Sugiyono, 2003. Metode Penelitian Bisnis. Bandung: Pusat Bahasa Depdiknas.

Suhendra, E. S. 2010. Pengaruh Tingkat Kepatuhan Wajib Pajak Badan Terhadap Peningkatan Penerimaan Pajak Penghasilan Badan. Jurnal Ekonomi Bisnis. (Vol. 15): 58-65.

Suryadi, 2006. Model Hubungan Kausal Kesadaran, Pelayanan, Kepatuhan Wajib Pajak dan Pengaruhnya Terhadap Kinerja Penerimaan Pajak: Suatu Survei di Wilayah Jawa Timur. Jurnal Keuangan Publik. (Vol. 04):105-121.

Tresno, Indra \& Wulan, 2011. Pengaruh Penambahan Wajib Pajak Badan, Penyampaian SPT Masa PPh Badan, dan Pengawasan Kepatuhan Wajib Pajak Badan terhadap Penerimaan Pajak Penghasilan Badan di KPP Pratama Jakarta Matraman. Universitas Negeri Jakarta Journal. 